\title{
Impact of Brick Kilns' Emission on Soil Quality of Agriculture Fields in the Vicinity of Selected Bhaktapur Area of Nepal
}

\author{
Gunjan Bisht $^{1}$ and Sanjila Neupane ${ }^{2}$ \\ ${ }^{1}$ Department of Natural Science, Kathmandu University, P.O. Box 6250, Dhulikhel, Nepal \\ ${ }^{2}$ Department of Environmental Science and Engineering, Kathmandu University, P.O. Box 6250, Dhulikhel, Nepal \\ Correspondence should be addressed to Gunjan Bisht; gunjanbisht31@gmail.com
}

Received 11 July 2015; Revised 15 September 2015; Accepted 15 September 2015

Academic Editor: Marco Trevisan

Copyright (c) 2015 G. Bisht and S. Neupane. This is an open access article distributed under the Creative Commons Attribution License, which permits unrestricted use, distribution, and reproduction in any medium, provided the original work is properly cited.

\begin{abstract}
The study was conducted to evaluate soil quality and impact of brick kiln on different physicochemical parameters of soils of agricultural field, located in the vicinity of Bhaktapur, Nepal. The study was carried out by determining the physicochemical characteristics of soil, soil fertility, and heavy metal contamination of soil. During the entire study period, water absorptivity of soil ranged from 2.4 to $3.3 \mathrm{mg} / \mathrm{L}, \mathrm{pH}$ varies from 5.885 to 7.64 , and organic carbon content and organic matter varied from 0.277 to $0.93 \%$, from $0.477 \%$ to $1.603 \%$, respectively. Nutrient content, that is, sulfate and nitrate concentration, in the soil ranged from 0.829 to $3.764 \mathrm{~mol} / \mathrm{L}$ and from 0.984 to $29.99 \mathrm{~mol} / \mathrm{L}$, respectively. The findings revealed that concentrations of heavy metals (chromium and lead) were within permissible limit, although the levels were higher in soil at $50 \mathrm{~m}$ and decrease farther from brick kiln. However, the physical parameters and nutrient content were deficient in soil at $50 \mathrm{~m}$ while increasing gradually at distances of $100 \mathrm{~m}$ and $150 \mathrm{~m}$. The variation of result obtained for physical parameters supports the fact that quality of soil in terms of heavy metal content and nutrient content was directly proportional to the distance from the kiln; that is, the quality of soil increased with increasing distance.
\end{abstract}

\section{Introduction}

Development of modern technologies has been a key determinant to accelerate industrialization and urbanization in developing countries like Nepal. But in a quest of rapid economic growth, developments are considered key priorities, while protection of environment has not been given the same importance. Thus, a number of factories, sited haphazardly, have been established leading to deterioration of natural resources like soil, water, and air. As a result, environment pollution is tremendously increasing due to industrialization and mechanization that is serving to fulfill demands of population. With increasing population, demand for bricks for construction is also increasing establishing brick industry as a booming industry [1].

The net result of a brick kiln is called land degradation. Land degradation is reduction of land quality. Productivity of soil declines when land becomes degraded. It declines unless steps are taken to restore that productivity and check further losses. Also data analyses on the brick fields from different study reveal that considerable amount of productive and potential agricultural lands has been given to brick fields. Unfortunately, brick fields are mostly situated on river line fertile agricultural land, as it needs clayish, silty, and loamy soil with good texture. Removal of fertile top soil leaves the land infertile [2]. Similarly, studies on brick kilns in Budgam District of Kashmir valley (India) also showed some major negative impacts on the environment in respect of air quality, human health, and vegetation in particular [3]. Similarly, soil, dust, and plant samples were collected from an agricultural area of Peshawar and heavy metal concentrations were analyzed. High levels of $\mathrm{Cr}$ and other heavy metals were found in soil, plant, and dust samples indicating that plants absorbed metals through their roots [4]. Likewise, study that was carried out on soil contamination in an industrial area, Surat in Gujarat (Western India), showed spatial variation in elemental composition of soil that was investigated by collecting and analyzing 25 surface soil samples confirming 
that the source of contamination is to be anthropogenic from industrial activity surrounding Surat soils [5]. Similar result about impact of brick kilns on overall environment of Khejuri was obtained leading to problem of land degradation [2].

Brick kilns in Nepal are mainly concentrated around Kathmandu valley and in terai regions. There are more than 500 brick kilns established in Nepal. These brick kilns remove topsoil for brick making; so this has direct impact on agricultural crop production as it reduced fertility status of soil. The negative impact of topsoil removal results in reduction in agricultural output and increases cost of replacing the nutrients lost. Release of harmful gases from the brick kilns to the environment alters the natural cycles such as nitrogen cycle and other natural processes which results in decreasing fertility, decreasing the change in composition and contents of nutrients in soil. This change in nutrient concentration increases heavy metal contents in soil reducing the overall quality [5]. Higher content of heavy metal lowers cation exchange capacity of soil, decreasing organic carbon content, and then reduces water holding capacity [6].

A considerable number of studies are available in literature regarding the impact of brick kiln or any industrial areas in developed countries. In context of Nepal, few studies have been done to indicate that brick kilns are responsible for polluting environment of which majority are based on the measurement of air polluting factors. This is the reason that necessary data are unavailable in developing countries like Nepal due to research gaps [7]. There is no study done to check or analyze soil quality affected due to these kilns established in residential areas and their impact on the agricultural soil around the brick kilns. Thus, there was a need of study to associate brick kiln pollution with its impression on environment. With the objective to analyze the impact of brick kiln on the agricultural soil, a field based study was carried out on area around brick kiln situated at Bhaktapur, Nepal.

For determining the impact of brick kiln, soil samples from distance of $50 \mathrm{~m}, 100 \mathrm{~m}$, and $150 \mathrm{~m}$ far from brick kiln in each of the four directions, that is, total 12 samples, were collected and analysis of these soil samples was done in the following three categories: impact on physical parameters of soil, which was determined by analyzing different physical parameters like soil texture, organic carbon content, organic matter content, water absorption capacity, and $\mathrm{pH}$. Similarly, soil fertility was obtained by determining the content of nutrients in soil, that is, sulfate and nitrate, using UV-Vis spectrophotometer. Further heavy metal contamination was determined by determining the amount of different heavy metals: chromium and lead in soil using AAS.

\section{Materials and Methods}

2.1. Site Selection. The selection of the brick kiln was based on nearness to agricultural lands as the study comprised determination of contamination in cropped land. For this purpose, brick kiln in Bhaktapur was selected that was surrounded by cropped area. This is representative of many such brick kilns not only in Bhaktapur but almost everywhere else in Nepal, where the kiln is in the center of farmland.
2.2. Collection of Soil Samples. Soil samples $(0-30 \mathrm{~cm}$ depth) from around brick kiln at distances of $50 \mathrm{~m}, 100 \mathrm{~m}$, and $150 \mathrm{~m}$ in four directions (east, west, north, and south) around the kilns were collected. Each of the 12 samples collected from the site was transferred into sealed plastic bags and labeled appropriately. The soil samples were labeled as $R D$, where $R$ is distance from brick kiln $(R=50 \mathrm{~m}, 100 \mathrm{~m}$, and $150 \mathrm{~m})$ and $D$ is the direction ( $D=$ east, west, north, and south). The samples were air-dried and external substances are removed. Samples were then sieved using sieving apparatus consisting of different sieve sizes $(10>0.075 \mathrm{~mm})$. Sieved samples $(>2 \mathrm{~mm})$ were preserved for further determination.

2.3. Extraction. $50 \mathrm{gm}$ sample was taken in a $250 \mathrm{~mL}$ conical flask from twelve locations around brick kiln. Exactly $50 \mathrm{~mL}$ of distilled water in 1:1 ratio was added to it and was shaken in mechanical shaker for 10 minutes. Then, the mixture was kept still for thirty minutes. Samples were filtered using filter paper. For turbid filtrates, samples were centrifuged using 3000 cycles/min centrifuge for 5 minutes.

2.4. Determination of Physical Parameters of Soil. $100 \mathrm{~mL}$ of distilled water was added to $10 \mathrm{gm}$ of soil taken in a glass funnel whose neck was fitted with wool glass. These samples were kept for 2-3 hours. In this duration, soil absorbs the water and water holding capacity was determined [8]. The soil texture was determined by international pipette method. The soil $\mathrm{pH}$ was determined with distilled water in a ratio (soil : water) of $1: 2.5(\mathrm{w} / \mathrm{v})$ using a $\mathrm{pH}$ meter (Orion 5-Star, Thermo) [9]. Triplet data for each sample was taken and average of the three was obtained. Organic carbon was determined by using the Walkley and Blake method and the organic matter by using a conversion factor of 1.724 .

2.5. Determination of Chemical Parameters of Soil. $25 \mathrm{~mL}$ glycerol was mixed with a solution containing $15 \mathrm{~mL}$ conc. $\mathrm{HCl}, 50 \mathrm{~mL}$ distilled water, $50 \mathrm{~mL}$ (95\%) isopropanol, and $37.5 \mathrm{~g} \mathrm{NaCl}$ to form conditional reagent. Likewise, the standard sulfate solution was prepared by weighing exactly $1.479 \mathrm{~g}$ of analytical grade anhydrous sodium sulfate and dissolving it in distilled water. Finally, using the conditional reagent, standard sulfate solution, and sample solution, sulfate analysis was carried out at wavelength of $420 \mathrm{~nm}$ using Thermo Scientific GENESYS 10S UV-Vis spectrophotometer [10].

A standard calibration curve of concentration $(\mathrm{mg} / \mathrm{L})$ versus absorbance was plotted for sulfate taking different concentration of standard solution and distilled water with specified amount of reagents [10]. Nitrate analysis of the soil sample was done by colorimetric determination in which nitrate is extracted with $0.01 \mathrm{M} \mathrm{CuSO}_{4}$ solution. A clear soil extract is obtained by using $\mathrm{CuSO}_{4}, \mathrm{Ca}(\mathrm{OH})_{2}$, and $\mathrm{MgCO}_{3}$. A nitrate in contact with $\mathrm{H}_{2} \mathrm{SO}_{4}$ produces nitric acid that causes nitration of position of 2,4-phenoldisulphonic acid in dry condition. The product is nitrophenolic-type indicator giving yellow color in alkaline medium which is determined colorimetrically measuring absorbance at $415 \mathrm{~nm}$ using Thermo Scientific GENESYS 10S UV-Vis spectrophotometer.

A standard calibration curve of concentration (mg/L) versus absorbance was plotted for nitrate by taking different 
TABle 1: Textural classes, organic carbon content and organic matter content of soil as influenced by distance from brick kiln chimney.

\begin{tabular}{|c|c|c|c|c|c|c|c|}
\hline Distance & Direction & Sand (\%) & Silt (\%) & Clay (\%) & Textural class & Organic carbon (\%) & Organic matter $(\%)$ \\
\hline \multirow{4}{*}{$50 \mathrm{~m}$} & East & 8.2 & 74.8 & 17 & Silt loam & 0.483 & 0.833 \\
\hline & West & 7 & 75.2 & 17.8 & Silt loam & 0.513 & 0.885 \\
\hline & North & & & Res $^{*}$ & & & \\
\hline & South & 11.2 & 71.1 & 17.7 & Silt loam & 0.277 & 0.477 \\
\hline \multirow{4}{*}{$100 \mathrm{~m}$} & East & 9 & 73 & 18 & Silt loam & 0.797 & 1.373 \\
\hline & West & 21 & 60 & 19 & Silt loam & 0.813 & 1.402 \\
\hline & North & & & Res $^{*}$ & & & \\
\hline & South & 13.2 & 70 & 16.8 & Silt loam & 0.720 & 1.241 \\
\hline \multirow{4}{*}{$150 \mathrm{~m}$} & East & 20.5 & 65.5 & 14 & Silt loam & 0.813 & 1.402 \\
\hline & West & 20 & 67 & 13 & Silt loam & 0.930 & 1.603 \\
\hline & North & 23 & 65 & 12 & Silt loam & 0.757 & 1.304 \\
\hline & South & 12 & 72 & 16 & Silt loam & 0.737 & 1.270 \\
\hline
\end{tabular}

${ }^{*}$ refers to residential area.

concentration of $\mathrm{NO}_{3}{ }^{-}$working solution and $\mathrm{NO}_{3}{ }^{-}$extracting solution [11]. Triplet data for each sample was taken and average of the three was obtained.

2.6. Heavy Metal Contamination on Soil. Heavy metals constitute an ill-defined group of inorganic chemical hazards. Brick kiln uses huge amount of coal and rubber tires as fuel for manufacturing brick in nonscientific way leading to adverse effect on environment. The metals most frequently identified at contaminated sites are lead $(\mathrm{Pb})$ and chromium (Cr) $[12,13]$. The analysis of lead and chromium was carried out using Flame Photometry Atomic Absorption Spectrometer (AAS) of Thermo Electron Company at AEC Lab in Kathmandu University. Triplet data for each sample was taken and average of the three was obtained.

\section{Result and Discussion}

3.1. Impact on Physical Parameters of Soil. The soil texture was determined by international pipette method $(<1 \mathrm{~mm}$ soil size). Soil texture classes were based on varying proportions of sand, silt, and clay, expressed as percentages [14]. The texture of the soil was determined based on the USDA textural classification. The texture of soil was found to be silt loam soil collected at $50 \mathrm{~m}, 100 \mathrm{~m}$, and $150 \mathrm{~m}$ from brick kiln (Figure 1, Table 1). Generally, these types of soil have the ability to retain moderate amount of organic matter $[15,16]$.

Organic carbon is important parameter of soil that determines beneficial effects on soil quality. It improves soil structure, enhances aeration and water penetration, increases water holding capacity, and supplies nutrients for growth of plants. Organic carbon levels greater than $0.8 \%$ are rated as good quality of soil [14]. A level of organic carbon greater than $0.75 \%$ indicates good fertility $[14,17]$. The percent of organic carbon in soil was determined titrimetrically using Walkley and Black method with oxidation of organic matter with potassium dichromate $\left(\mathrm{K}_{2} \mathrm{Cr}_{2} \mathrm{O}_{7}\right)$. Organic carbon of the soil in this study area ranged from $0.277 \%$ to $0.93 \%$ (Table 1). The lowest concentration of organic carbon was recorded as $0.277 \%$ at the soil at $50 \mathrm{~m}$ south of brick kiln

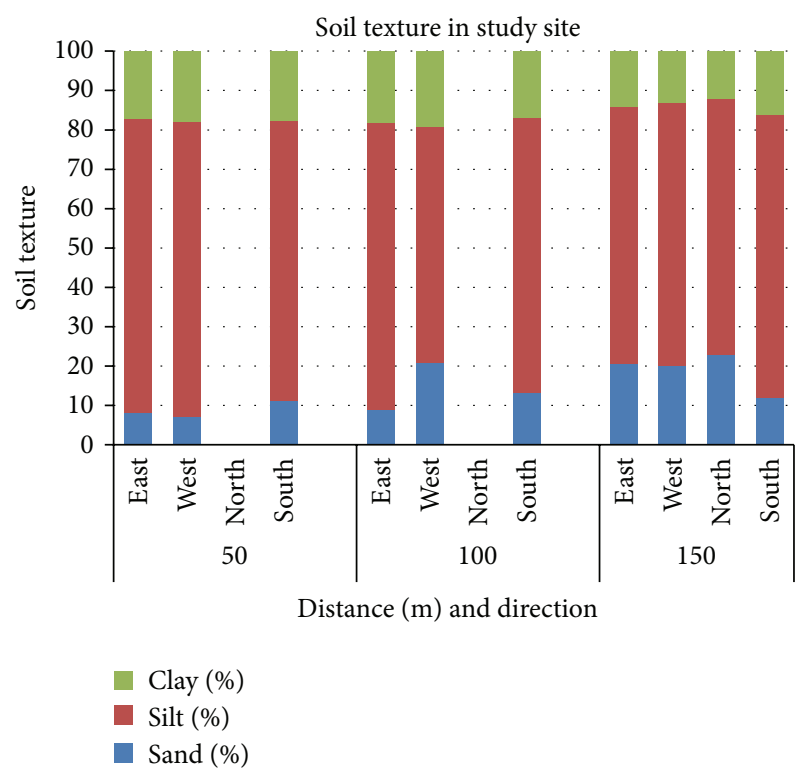

FIGURE 1: Graphical representation of soil texture of study site.

and the highest was $0.93 \%$ at $150 \mathrm{~m}$ west of brick kiln. The variation of organic carbon may be the result of the variation of organic matter practices and also it is directly related to surface soil removal process. Organic carbon level in soil samples near to brick kiln has been found poor in range. Because of the stabilizing properties that clay has on organic matter, soil texture affects Soil Organic Carbon (SOC) [14]. However, relatively low concentration in south $50 \mathrm{~m}$ is due to the added effect of smoke from vehicles as the KathmanduBhaktapur section of Araniko highway runs in the direction.

Organic matter is the major source of nutrients in soil. The organic matter of soil in the studied area varied between $0.477 \%$ and $1.603 \%$ (Table 1 ). The organic matter near to the brick kiln was found low due to low organic carbon content. The organic matter content in soil gradually increased with distance away from the kiln; however, the higher concentration in west rather than any other direction is attributed to higher use of fertilizers in the cultivated 
TABLE 2: $\mathrm{pH}$ of soil as influenced by distance from brick kiln chimney.

\begin{tabular}{lccc}
\hline $\begin{array}{l}\text { Direction with } \\
\text { respect to }\end{array}$ & \multicolumn{3}{c}{ Distance from brick kiln (meters) } \\
Brick kiln & 50 & 100 & 150 \\
\hline East & $6.860 \pm 0.0058$ & $6.915 \pm 0.0012$ & $6.355 \pm 0.0007$ \\
West & $6.985 \pm 0.0026$ & $6.15 \pm 0.0153$ & $7.1 \pm 0.0115$ \\
North & Res* $^{*}$ & Res $^{*}$ & $6.465 \pm 0.0009$ \\
South & $7.2 \pm 0.0033$ & $6.59 \pm 0.002$ & $6.39 \pm 0.0033$ \\
\hline
\end{tabular}

${ }^{*}$ refers to residential area.

TABLE 3: Water absorptivity in soil ( $\mathrm{mg} / \mathrm{L})$ as influenced by distance from brick kiln chimney.

\begin{tabular}{lccc}
\hline $\begin{array}{l}\text { Direction with } \\
\text { respect to }\end{array}$ & \multicolumn{3}{c}{ Distance from brick kiln (meters) } \\
Brick kiln & 50 & 100 & 150 \\
\hline East & 2.4 & 2.55 & 2.25 \\
West & 2.4 & 2.7 & 2.4 \\
North & Res $^{*}$ & Res $^{*}$ & 3.0 \\
South & 3.3 & 2.3 & 2.9 \\
\hline
\end{tabular}

${ }^{*}$ refers to residential area.

field while relatively low concentration in south is due to aerial deposits of vehicles running in Kathmandu-Bhaktapur section of Araniko highway.

Soil $\mathrm{pH}$ is an important index of ecological condition of terrestrial environment [14]. It affects the availability of nutrients to plants and the activity of soil microorganisms. Also, soil can be the deposit or carrier of toxic substances such as heavy metals and $\mathrm{pH}$ lowering (acidifying) agents. The maximum availability of the primary nutrient like nitrogen, phosphorus, and potassium as well as secondary nutrients like sulphur, calcium, and magnesium is found in the $\mathrm{pH}$ range of 6.5 to $7.5[14,17]$. Also, it is reported that the $\mathrm{pH}$ of soils increases the mobility of $\mathrm{Pb}, \mathrm{Cd}, \mathrm{Cr}, \mathrm{Cu}, \mathrm{Hg}, \mathrm{Ni}$, and $\mathrm{Zn}$ in case of acidity while in alkaline condition the reverse phenomenon takes place. $\mathrm{pH}$ provides a good identification of soil chemical nature where higher $\mathrm{pH}$ indicated optimal range for plant growth but lower $\mathrm{pH}$ causes problems for normal growth of the plants [14]. The $\mathrm{pH}$ values of the samples ranged from 5.885 to 7.64 (Table 2). Recorded $\mathrm{pH}$ of soil samples ranged from slightly acidic to neutral. The $\mathrm{pH}$ of soil samples at $50 \mathrm{~m}$ east and west is 6.8 , which shows slight acidic character, so it clearly refers impact from brick kiln. The southern soil sample is neutral. The $\mathrm{pH}$ of soil at $100 \mathrm{~m}$ north is 5.8 which decreases soil microbial activity.

Water absorptivity is another factor that determines the quality of soil. Soil should be capable of absorbing adequate moisture. If water is lost to the soil then soil quality deteriorates. Water holding capacity of soil influences crop growth, rotting pattern, and ability to supply water to crops during dry period [18]. The water absorptivity of samples obtained has variable values as there are various factors affecting the result. Towards south of brick kiln's chimney, the presence of Kathmandu-Bhaktapur road section of Araniko highway
TABLE 4: Concentration of sulfate $\left(\mathrm{mol} \mathrm{L}^{-1}\right)$ in soil as influenced by distance from brick kiln chimney.

\begin{tabular}{lccc}
\hline $\begin{array}{l}\text { Direction with } \\
\text { respect to }\end{array}$ & \multicolumn{3}{c}{ Distance from brick kiln (meters) } \\
Brick kiln & 50 & 100 & 150 \\
\hline East & $1.398 \pm 0.00058$ & $1.967 \pm 0.00006$ & $2.133 \pm 0.00058$ \\
West & $2.730 \pm 0.00012$ & $2.834 \pm 0.00058$ & $3.764 \pm 0.00115$ \\
North & Res $^{*}$ & Res $^{*}$ & $0.933 \pm 0.01155$ \\
South & $0.905 \pm 0.000$ & $0.829 \pm 0.00007$ & $0.870 \pm 0.001$ \\
\hline
\end{tabular}

${ }^{*}$ refers to residential area.

TABLE 5: Concentration of nitrate $\left(\mathrm{mol} \mathrm{L}^{-1}\right)$ in soil as influenced by distance from brick kiln chimney.

\begin{tabular}{lccc}
\hline $\begin{array}{l}\text { Direction with } \\
\text { respect to }\end{array}$ & \multicolumn{3}{c}{ Distance from brick kiln (meters) } \\
Brick kiln & 50 & 100 & 150 \\
\hline East & $2.136 \pm 0.000$ & $2.974 \pm 0.00058$ & $3.079 \pm 0.00079$ \\
West & $8.052 \pm 0.00115$ & $23.55 \pm 0.00058$ & $29.99 \pm 0.00058$ \\
North & Res. $^{*}$ & Res. $^{*}$ & $0.984 \pm 0.00115$ \\
South & $2.188 \pm 0.00058$ & $2.503 \pm 0.001$ & $2.817 \pm 0.001$ \\
\hline *refers to residential area. & &
\end{tabular}

causes decrease in water absorptivity at distance. When compared, the values across the distances of east and west directions show increasing trend with increase in distance from chimney (Table 3). When the soil loses more water, its infiltration capacity worsens and, consequently, there is drastic change in depth in water level. Changed soil texture because of repeated heating does not permit the rain water to infiltrate to form the groundwater. The resultant effect is lowering down of depth to water level and the area emerged as unfertile land which was highly productive and fertile area prior to brick kiln industry.

3.2. Impact on Soil Fertility. The absorbance of sample taken from three different distances from four directions was obtained with UV-Vis spectrophotometer at wavelength of $420 \mathrm{~nm}$ for sulfate and at $415 \mathrm{~nm}$ for nitrate while calculation of concentration was done using calibration curve.

The analyzed soil samples, taken across all directions, revealed that sulfate concentration in the soil at four different directions from the brick kiln chimney at distances of $50 \mathrm{~m}$, $100 \mathrm{~m}$, and $150 \mathrm{~m}$ ranged from 0.829 to $3.764 \mathrm{~mol} / \mathrm{L}$ (Table 4) and for nitrate it ranged from 0.984 to $29.99 \mathrm{~mol} / \mathrm{L}$ (Table 5). Brick kiln chimney distance effect on sulfate and nitrate concentration is evident from the data. Towards $150 \mathrm{~m}$ west from the kiln's chimney consisting of cultivated field, nitrate concentration was the highest, that is, $3.764 \mathrm{~mol} / \mathrm{L}$, while at $50 \mathrm{~m}$ distance from the chimney it was low, that is, $2.730 \mathrm{~mol} / \mathrm{L}$, indicating effect of brick kiln induced contamination as the distance from kiln chimney increased. Similarly, nitrate concentration was the highest at $150 \mathrm{~m}$ distance, that is, $29.99 \mathrm{~mol} / \mathrm{L}$, while at $50 \mathrm{~m}$ distance from the chimney it was low, that is, $8.052 \mathrm{~mol} / \mathrm{L}$. The higher concentration in west rather than any other direction is attributed to higher use 
TABLE 6: Concentration of lead ( $\mathrm{mg} / \mathrm{kg}$ ) in soil as influenced by distance from brick kiln chimney.

\begin{tabular}{lccc}
\hline $\begin{array}{l}\text { Direction with } \\
\text { respect to }\end{array}$ & \multicolumn{3}{c}{ Distance from brick kiln (meters) } \\
Brick kiln & 50 & 100 & 150 \\
\hline East & $8.18 \pm 0.0058$ & $8.18 \pm 0.0115$ & $5.45 \pm 0.0153$ \\
West & $11.82 \pm 0.0115$ & $8.18 \pm 0.0088$ & $7.27 \pm 0.000$ \\
North & Res $^{*}$ & Res $^{*}$ & $5.45 \pm 0.0058$ \\
South & $9.09 \pm 0.0058$ & $8.18 \pm 0.015$ & $10 \pm 1.000$ \\
\hline
\end{tabular}

${ }^{*}$ refers to residential area.

of fertilizers in the field. When compared, the concentration values across the distances of east and south directions show increasing trend with increase in distance from chimney. Sulfate concentration across south ranges from $0.829 \mathrm{~mol} / \mathrm{L}$ at $100 \mathrm{~m}$ to $0.905 \mathrm{~mol} / \mathrm{L}$ at $50 \mathrm{~m}$ while for nitrate it ranges from $2.188 \mathrm{~mol} / \mathrm{L}$ at $50 \mathrm{~m}$ to $2.817 \mathrm{~mol} / \mathrm{L}$ at $150 \mathrm{~m}$. This relatively low concentration in south is the added effect of smoke from vehicles as the Kathmandu-Bhaktapur section of Araniko highway runs in the direction [19].

Analyzing the results across different distance along all direction, the concentration of sulfate and nitrate content in soil is higher at farther distance from brick kiln. This implies that the decrease in sulfate and nitrate content at $50 \mathrm{~m}$ and $100 \mathrm{~m}$ from brick kiln is due to the impact. Apart from this, the overall decrease of sulfate content in soil is because leaching of sulfate may be caused by raining months ago from date of sample collection and also due to the wet soil where rice was planted.

3.3. Impact on Soil due to Heavy Metal Contamination. The average metal concentration showed a diverse variation with respect to direction and distance. The analyzed soil samples observed across all directions revealed that $\mathrm{Pb}$ concentration ranged from 5.45 to $11.82 \mathrm{mg} / \mathrm{kg}$ (Table 6). When these concentrations were compared with US EPA standards, it was found within the permissible limit of lead in soil (2$200 \mathrm{mg} / \mathrm{kg}$ ) [20, 21]. Presence of lead in this environment may have been due to automobile emission and industrial emission [22]. Across all directions of brick kilns, $\mathrm{Pb}$ concentration was the highest at $50 \mathrm{~m}$, that is, $11.82 \mathrm{mg} / \mathrm{kg}$, which may be due to the burning of tyres during the baking of bricks, while at $150 \mathrm{~m}$ distance from chimney it was low, that is, $5.45 \mathrm{mg} / \mathrm{kg}$, indicating effect of brick kiln induced contamination as the distance from kiln chimney increased similar to the results obtained by [15].

The chromium concentration in the soil samples ranged from 1.67 to $10.005 \mathrm{mg} / \mathrm{kg}$ (Table 7) which was within the permissible range of chromium in soil $(1-1000 \mathrm{mg} / \mathrm{kg})$ when compared with US EPA standards [20,21]. Across all directions of brick kilns, $\mathrm{Cr}$ concentration was the highest at $50 \mathrm{~m}$, that is, $10.005 \mathrm{mg} / \mathrm{kg}$, while at $150 \mathrm{~m}$ distance from chimney it was low, that is, $1.67 \mathrm{mg} / \mathrm{kg}$. This showed increase in effect of contamination as the distance from kiln chimney increased. Similar results were reported by $[4,15]$ where they also noticed variations of $\mathrm{Cr}$ concentration with distance from
TABLE 7: Concentration of chromium $(\mathrm{mg} / \mathrm{kg})$ in soil as influenced by distance from brick kiln chimney.

\begin{tabular}{lccc}
\hline $\begin{array}{l}\text { Direction with } \\
\text { respect to }\end{array}$ & \multicolumn{3}{c}{ Distance from brick kiln (meters) } \\
Brick kiln & 50 & 100 & 150 \\
\hline East & $10.002 \pm 0.0003$ & $1.676 \pm 0.0007$ & $1.676 \pm 0.0003$ \\
West & $6.673 \pm 0.0009$ & $6.673 \pm 0.0006$ & $3.331 \pm 0.0006$ \\
North & Res $^{*}$ & Res $^{*}$ & $1.67 \pm 0.0067$ \\
South & $10.005 \pm 0.0006$ & $8.339 \pm 0.0002$ & $6.67 \pm 0.0058$ \\
\hline
\end{tabular}

${ }^{*}$ refers to residential area.

brick kilns. Constant values were obtained across east, that is, $1.676 \mathrm{mg} / \mathrm{kg}$ along distances 100 and $150 \mathrm{~m}$, and across west, that is, $6.673 \mathrm{mg} / \mathrm{kg}$ along distances 50 and $100 \mathrm{~m}$.

The difference in the concentration of metals with distance might be attributed to the fallout of pollutants a few meters away from the source depending upon the direction and velocity of wind. Comparing the directions, south of brick kiln seems to have higher contamination of lead and chromium that is attributed to heavy input of aerial deposits due to the presence of Kathmandu-Bhaktapur road section of Araniko highway in the direction $[4,23]$.

3.4. Correlation between Different Parameters of Soil. A correlation study was also performed to establish a correlation between different parameters of soil.

Figure 2 suggested that the chromium accumulation rate in soil decreased with the increasing concentrations of sand in that soil. In contrast, $\mathrm{Cr}$ highly accumulated in clay compared with that of silt and it results in slight $\mathrm{Cr}$ contamination in soil.

Similarly, Figure 3 suggested that the lead accumulation rate in soil decreased with the increasing concentrations of sand in that soil. In contrast, Pb highly accumulated in clay compared with that of silt.

Further study suggested that both $\mathrm{Cr}$ and $\mathrm{Pb}$ accumulation rate in soil slightly increased with the increasing $\mathrm{pH}$ concentrations of soil as shown in Figure 4.

For both heavy metals chromium $(\mathrm{Cr})$ and lead $(\mathrm{Pb})$, an inversely proportional relation between their accumulation rate and concentrations of organic carbon was studied, which indicates that with an increasing in heavy metal concentration a significant decrease in the organic carbon of soil was observed (Figure 5).

Result from Figures 6 and 7 suggested that both nitrate and sulfate concentration in soil decreased with the increasing concentrations of silt and clay in soil while they increased with concentration of sand.

\section{Conclusion}

After the analysis of soil samples taken from different distances from the brick kiln area, a general conclusion that could be reached is that the soil quality is degrading with increase in heavy metal content and decrease in nutrients like sulfate and nitrate. As we move away from brick kiln, the soil 


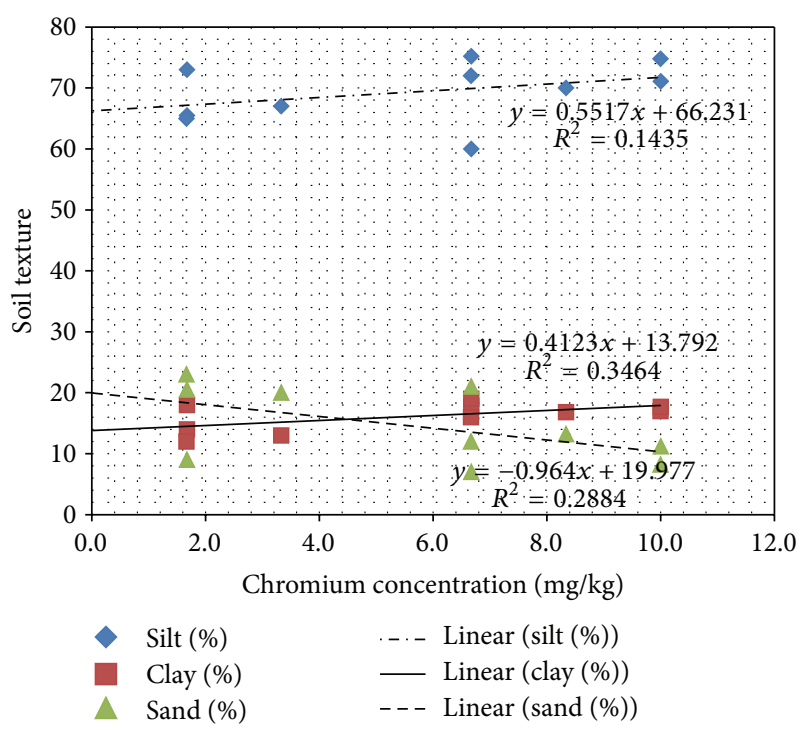

FIGURE 2: Correlation between chromium concentration and soil texture.

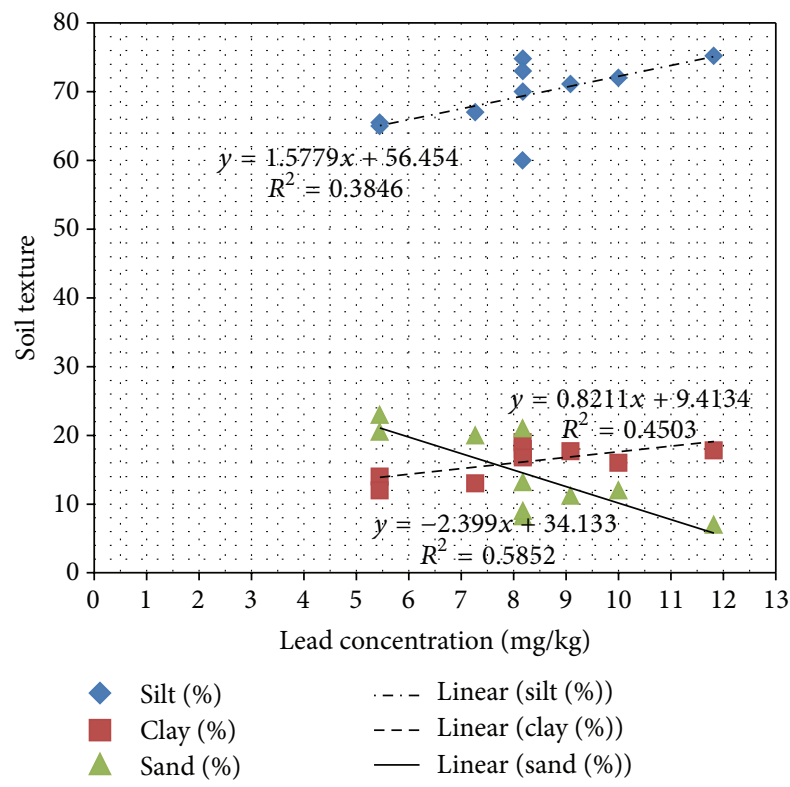

FIgURE 3: Correlation between lead concentration and soil texture.

quality is increasing steadily but slowly. The $\mathrm{pH}$ of soil was acidic near the kiln and neutral farther away, so does water absorptivity of soil, which increases farther away from kiln's chimney. The organic carbon content and organic matter content also increased with increasing distance. The available sulfate and nitrate level in soil samples examined had similar impact with increasing distance away from kiln's chimney. The level of heavy metals was within nontoxic limit. However, the concentrations of metals were higher in soil near kiln than in that farther from kiln causing soil contamination and degrading quality of soil health [24]. Although the range of physical and chemical parameters of soil is within the permissible limit, their concentration is not uniform and

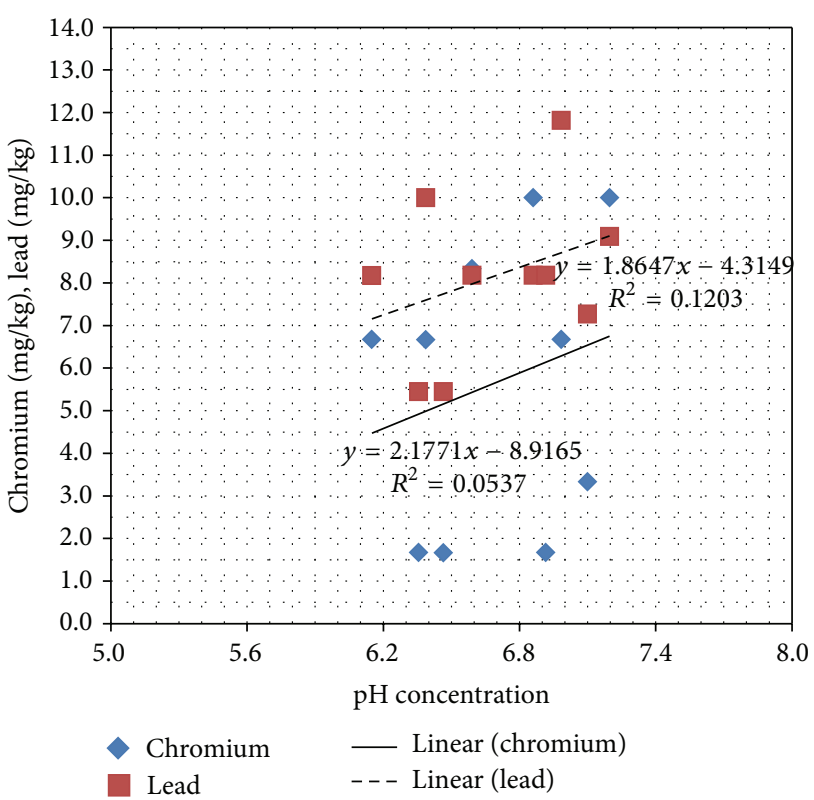

FIGURE 4: Correlation between heavy metals and $\mathrm{pH}$ concentration.

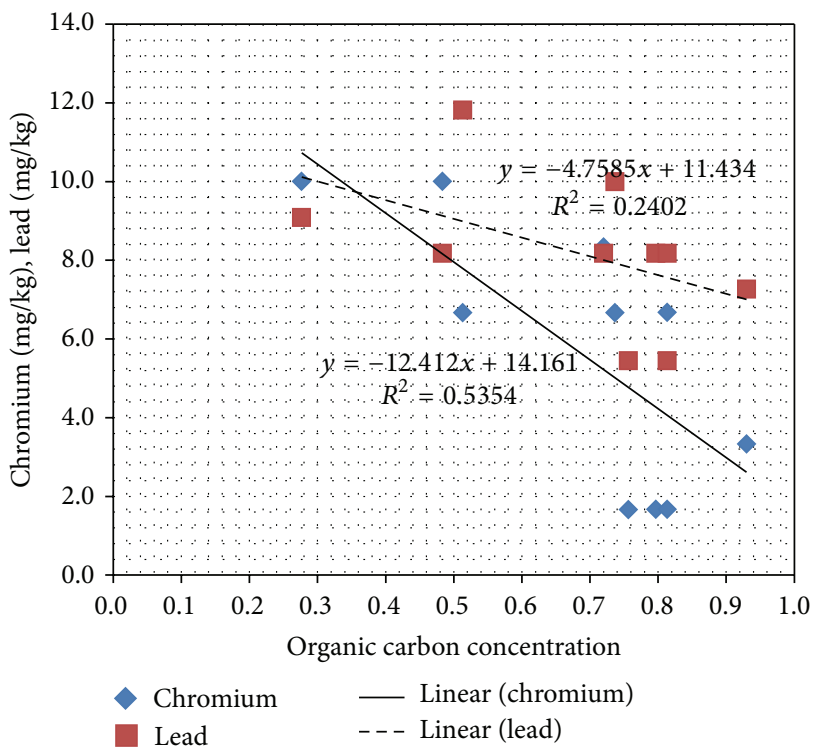

FIGURE 5: Correlation between heavy metals and organic carbon concentration.

rather varies with distance. This indicates deterioration of soil quality, so it is not found to be environmentally safe for agriculture [17]. Also, the cumulative effect of the brick kilns might further increase the levels of heavy metal content in the soil. Therefore, it is highly recommended that periodic survey must be done to monitor this effect and to ensure that appropriate actions can be taken before this happens. Also, since the quality of soil (nutrient content and heavy metal content taken as objective parameters for the soils quality) was better as we moved further from the brick kilns here in question, it would be safe to say that the "quality of the soil is directly proportional to its distance from the brick kiln." 


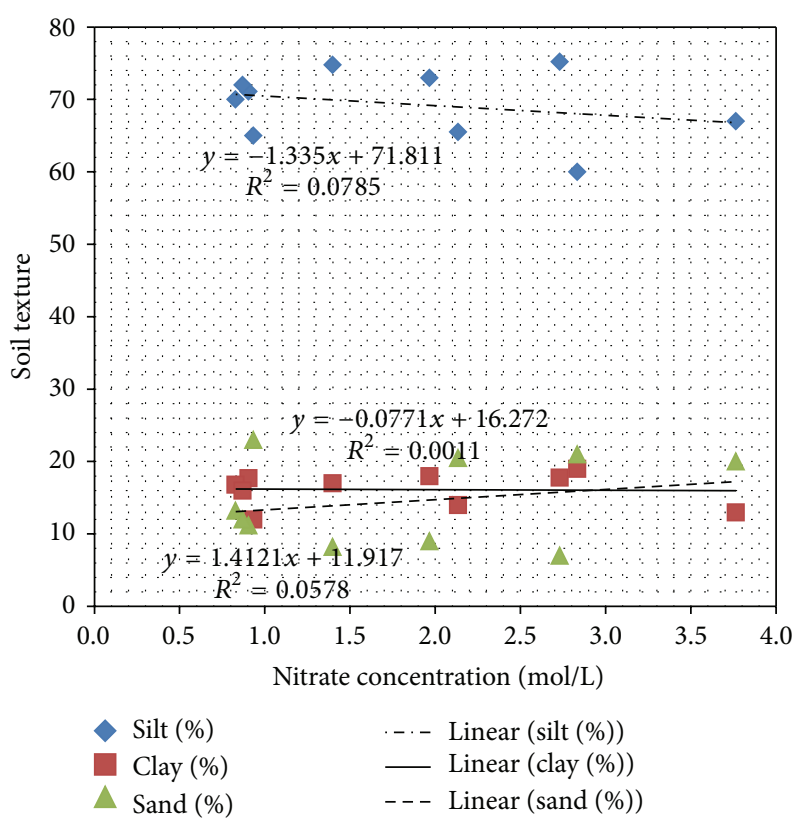

Figure 6: Correlation between nitrate concentration and soil texture.

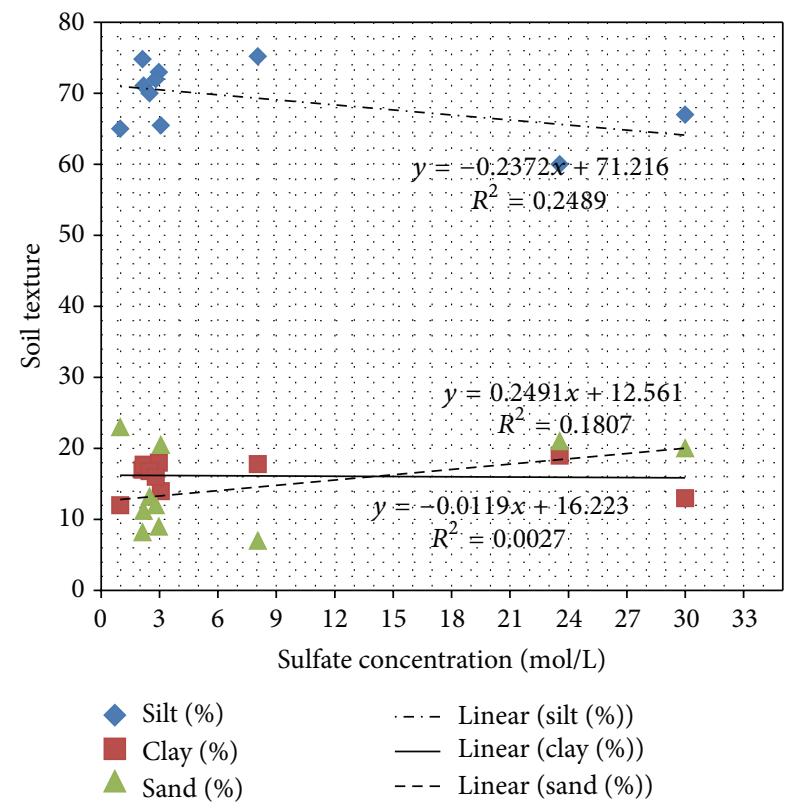

FIgURE 7: Correlation between sulfate concentration and soil texture.

\section{Conflict of Interests}

The authors declare no conflict of interests.

\section{Acknowledgment}

The authors acknowledge Department of Natural Science, Kathmandu University, Dhulikhel, Nepal, for providing all the support during the study period. The authors also acknowledge Roshan Kafle, Savara Gautam, Diksha Dhakal, and Nabin Chaudhary, students of Department of Environmental Science and Engineering, for their contribution during this study.

\section{References}

[1] B. M. Skinder, A. K. Pandit, A. Q. Sheikh, and B. A. Ganai, "Brick kilns: cause of atmospheric pollution," Pollution Effects and Control, vol. 2, no. 2, article 112, 2014.

[2] R. Das, "Causes and consequences of land degradation in and around the brick kilns of khejuri CD blocks over Coastal Medinipur in West Bengal," International Journal of Innovative Research and Development, vol. 4, no. 2, 2015, http://www.ijird.com/index.php/ijird/article/view/60825.

[3] B. Skinder M, A. Sheikh Q, A. Pandit K, and B. GanaiA, "Brick kiln emissions and its environmental impact: a review," Journal of Ecology and the Natural Environment, vol. 6, no. 1, pp. 1-11, 2014.

[4] M. Ismail, D. Muhammad, F. U. Khan et al., "Effect of brick kiln's emissions on heavy metal (CD and CR) content of contiguous soil and plants," Sarhad Journal of Agriculture, vol. 28, no. 3, pp. 403-409, 2012

[5] A. K. Krishna and P. K. Govil, "Soil contamination due to heavy metals from an industrial area of Surat, Gujarat, Western India," Environmental Monitoring and Assessment, vol. 124, no. 1, pp. 263-275, 2007.

[6] A. A. Duker, E. J. M. Carranza, and M. Hale, "Arsenic geochemistry and health," Environment International, vol. 31, no. 5, pp. 631-641, 2005.

[7] A. Gurung and M. L. Bell, "The state of scientific evidence on air pollution and human health in Nepal," Environmental Research, vol. 124, pp. 54-64, 2013.

[8] R. Soni and R. Bhaskar, "Impact of steel industry waste on physico-chemical property of soil," International Journal of Environmental Sciences, vol. 2, no. 3, pp. 1144-1153, 2012.

[9] X. Zhang, F. Li, T. Liu et al., "The variations in the soil enzyme activity, protein expression, microbial biomass, and community structure of soil contaminated by heavy metals," ISRN Soil Science, vol. 2013, Article ID 803150, 12 pages, 2013.

[10] T. E. Kipngetich, M. Hillary, and T. Anthoney Swamy, "Determination of levels of phosphates and sulfates in domestic water from three selected springs in Nandi County, Kenya," International Journal of Pharmacy \& Life Sciences, vol. 4, no. 7, pp. 2828-2833, 2013.

[11] P. K. Gupta, Soil, Plant, Water and Fertilizer Analysis, Agrobios, New Delhi, India, 2000.

[12] R. A. Wuana and F. E. Okieimen, "Heavy metals in contaminated soils: a review of sources, chemistry, risks and best available strategies for remediation," ISRN Ecology, vol. 2011, Article ID 402647, 20 pages, 2011.

[13] GWRTAC, "Remediation of metals-contaminated soils and groundwater," GWRTAC-E Series TE-97-01, GWRTAC, Pittsburgh, Pa, USA, 1997.

[14] S. Yaseen, A. Pal, S. Singh, and B. M. Skinder, "Soil quality of agricultural fields in the vicinity of selected mining areas of Raniganj Coalfield India," Journal of Environmental \& Analytical Toxicology, vol. 5, no. 3, article 269, 2015.

[15] K. Achakzai, S. Khalid, and A. Bibi, "Determination of heavy metals in agricultural soil adjacent to functional Brick Kilns: a case study of Rawalpindi," Science, Technology and Development, vol. 34, no. 3, pp. 122-129, 2015. 
[16] P. Tammeorg, A. Simojoki, P. Mäkelä, F. L. Stoddard, L. Alakukku, and J. Helenius, "Biochar application to a fertile sandy clay loam in boreal conditions: effects on soil properties and yield formation of wheat, turnip rape and faba bean," Plant and Soil, vol. 374, no. 1, pp. 89-107, 2014.

[17] A. B. Ghosh, J. C. Bajaj, R. Hassan, and D. Singh, Laboratory Manual for Soil and Water Testing 1st Edition, Soil Testing Laboratory, Division of Soil Science and Agricultural Chemistry, IARI, New delhi, India, 1983.

[18] P. Debnath, P. Deb, D. Sen, S. K. Pattannaik, D. Sah, and S. K. Ghosh, "Physico-chemical properties and its relationship with water holding capacity of cultivated soils along altitudinal gradient in Sikkim," International Journal of Agriculture, Environment and Biotechnology, vol. 5, no. 1, pp. 99-102, 2012.

[19] S. W. Li, J. K. Fredrickson, M. W. Ligotke, P. van Voris, and J. E. Rogers, "Influence of smoke exposure on soil enzyme activities and nitrification," Biology and Fertility of Soils, vol. 6, no. 4, pp. 341-346, 1988.

[20] J. E. McLean and B. E. Bledsoe, "Behavior of metals in soils," Ground Water Issue EPA/540/S-92/018, United States Environmental Protection Agency, 1992.

[21] C. J. Rosen, Lead in the Home Garden and Urban Soil Environment, Communication and Educational Technology Services, University of Minnesota Extension, Saint Paul, Minn, USA, 2002.

[22] E. D. Udosen, E. G. Ukpong, J. E. Asuquo, and E. E. Etim, "Trace metal levels in soils within an abandoned steel industry environment," International Journal of Modern Analytical and Separation Sciences, vol. 1, no. 1, pp. 64-69, 2012.

[23] D. Turer, J. B. Maynard, and J. J. Sansalone, "Heavy metal contamination in soils of urban highways: comparison between runoff and soil concentrations at Cincinnati, Ohio," Water, Air, and Soil Pollution, vol. 132, no. 3-4, pp. 293-314, 2001.

[24] S. H. Rahman, D. Khanam, T. M. Adyel, M. S. Islam, M. A. Ahsan, and M. A. Akbor, "Assessment of heavy metal contamination of agricultural soil around dhaka export processing zone (DEPZ), bangladesh: implication of seasonal variation and indices," Applied Sciences, vol. 2, no. 4, pp. 584-601, 2012. 

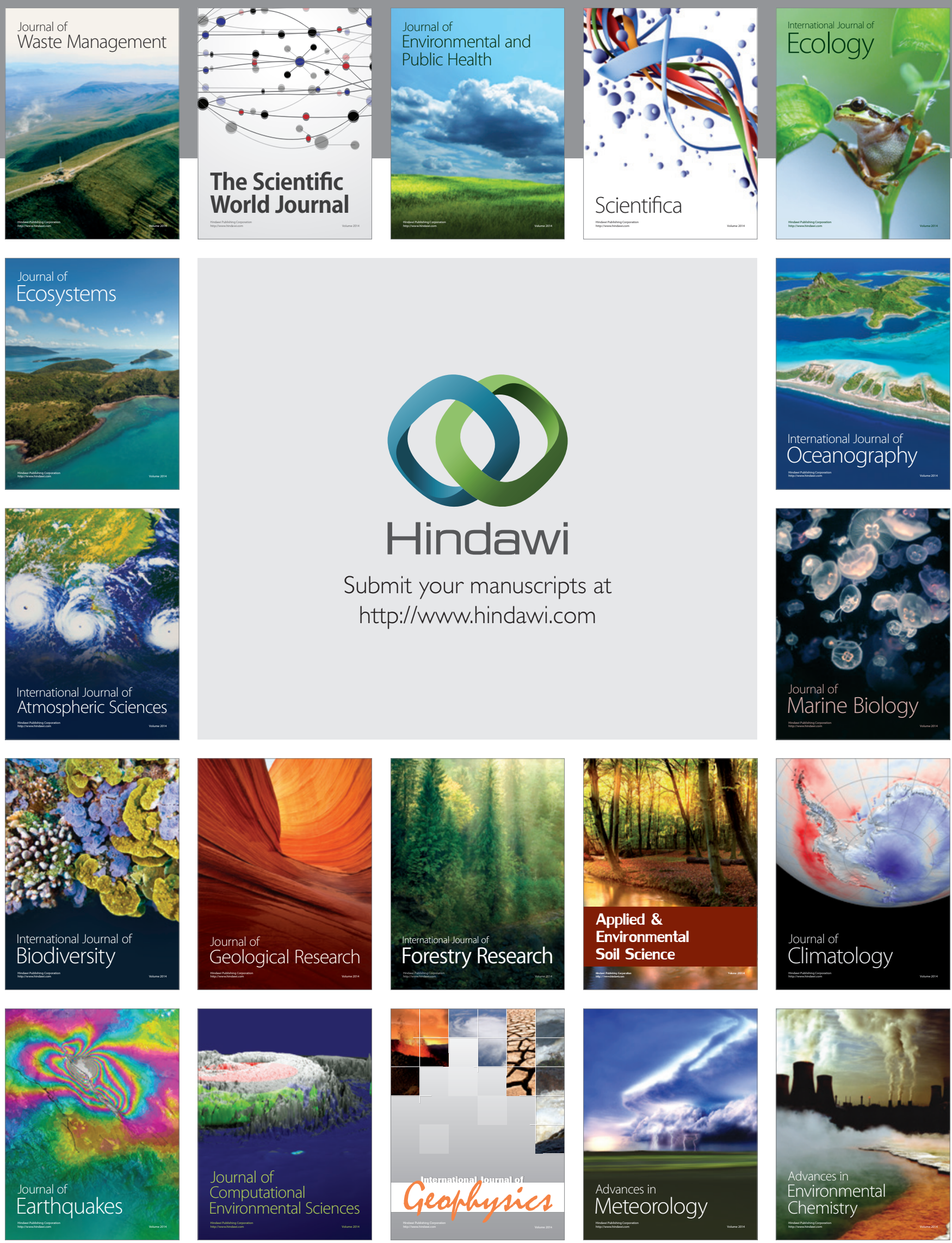